sooner. We now advocate that a recently head-injured patient should have a CT scan if he has either altered consciousness or other neurological signs or symptoms that do not improve after initial assessment and resuscitation. When there is a skull fracture the indications for scanning are increased; even by itself a fracture probably provides an adequate reason.

\section{References}

' Mendelow AD, Karmi MZ, Paul KS, Fuller GAG, Gillingham FJ. Extradural haematoma: effect of delayed treatment. $\mathrm{Br} \mathrm{Med} \mathcal{F} 1979$; : 1240-2

2 Seelig JM, Becker DP, Miller JD, et al. Traumatic acute subdural hematoma. Major mortality reduction in comatose patients treated within four hours. $N$ Engl 7 Med $1981 ; 304: 1511-8$.

3 Jennett B, Murray A, Carlin J, McKean M, MacMillan R, Strang I. Head injuries in three Scottish neurosurgical units. Br Med f 1979;ii:955-8.

4 Galbraith S. Misdiagnosis and delayed diagnosis in traumatic intracranial haematoma. Br Med f 1976; i:1438-9.

5 Rose J, Valtonen $S$, Jennett B. Avoidable factors contributing to death after head injury. $\mathrm{Br}$ Med f 1977;ii:615-8.

6 Jennett B, Carlin J. Preventable mortality and morbidity after head injury. Injury $1978 ; 10: 31-9$.

Jeffreys RV, Jones JJ. Avoidable factors contributing to the death of head injury patients in general hospitals in Mersey region. Lancet 1981 ;ii: 459-61.

${ }^{8}$ Ambrose J, Gooding MR, Uttley D. EMI scan in the management of head injuries. Lancet $1976 ; \mathrm{i}: 847-8$.

9 Jeffreys RV, Lozada L. The use of the CAT scan in the management of patients with head injury transferred to the regional neurosurgical unit. Injury 1982;13:370-4.

10 Teasdale G, Galbraith S. Extradural haematoma: effect of delayed treatment. Br Med f 1979;i:1793.

11 Teasdale G, Galbraith S. Acute traumatic intracranial haematomas. In Krayenbuhl H, Maspes PE, Sweet WH, eds. Progress in neurological surgery. Vol 10. Basle: Karger, $1981: 252-90$.

12 Teasdale G, Jennett B. Assessment and prognosis of coma after head injury. Acta Neurochir (Wien) 1976;34:45-55.

13 Jennett $B$, Bond $M$. Assessment of outcome after severe brain damage. Lancet $1974 ;$ i:480-4.

14 Baker IA. Availability of computed tomography for the management of head injuries in England and Wales. Br Med 7 1982;285:487-9.

15 Galbraith S, Teasdale G. Predicting the need for operation in the patient with an occult traumatic intracranial hematoma. $\mathcal{f}$ Neurosurg $1981 ; 55$ : 75-81.

16 Bartlett JR, Neil-Dwyer G. Clinical study of the EMI scanner: implications for provision of neuroradiological services. $\mathrm{Br}$ Med $\mathcal{f} 1978$;ii: 813-5.

17 Weston PAM. Admission policy for patients following head injury. $\mathrm{Br} \mathcal{F}$ Surg $1981 ; 68: 633-64$.

(Accepted 8 October 1982)

\title{
Converting-enzyme inhibitor enalapril (MK421) in treatment of hypertension with renal artery stenosis
}

\author{
G P HODSMAN, J J BROWN, D L DAVIES, R FRASER, A F LEVER, J J MORTON, \\ G D MURRAY, J I S ROBERTSON
}

\begin{abstract}
Enalapril maleate (MK421), a new inhibitor of angiotensin converting enzyme, in single daily doses of $1.25-40 \mathrm{mg}$ was assessed in five patients with hypertension and renal artery stenosis. Only small falls in plasma angiotensin II concentrations were seen at doses less than $10 \mathrm{mg}$; even with 10 and $20 \mathrm{mg}$, angiotensin II concentrations had risen again 24 hours from the last dose. During long-term treatment with $10-40 \mathrm{mg}$ daily all patients achieved good blood-pressure control. No significant changes of body sodium or potassium values were seen. The drug was well tolerated with no serious side effects.

These findings are evidence of the efficacy and acceptability of enalapril in the medical management of hypertension with renal artery stenosis.
\end{abstract}

MRC Blood Pressure Unit, Western Infirmary, Glasgow G11 6NT G P HODSMAN, MRCP, medical registrar

J J BROWN, FRCP, consultant physician

R FRASER, PHD, scientist

A F LEVER, FRCP, consultant physician

J J MORTON, PHD, scientist

J I S ROBERTSON, FRCP, consultant physician

Gardiner Institute of Medicine, Western Infirmary, Glasgow G11 6NT

D L DAVIES, FRCP, senior lecturer in medicine

Department of Statistics, Glasgow University, Glasgow G12 $80 Q$ G D MURRAY, PHD, lecturer in statistics

\section{Introduction}

We have reported ${ }^{1}$ the use preoperatively of the convertingenzyme inhibitor captopril in the treatment of hypertension associated with unilateral renal artery stenosis. Long-term captopril promised well as a predictor of the blood-pressure response to operation, although this requires further study. We have also reported that oral captopril in a dose of $150 \mathrm{mg}$ three times daily produces sustained suppression of the plasma angiotensin II concentration throughout 24 hours. ${ }^{2}$ Captopril, however, has been associated with several toxic effects which may be attributable to the sulphydryl group in its molecule. ${ }^{3}$ Although the use of lower doses of captopril may avoid at least some of these unwanted effects, it appears important to consider alternative converting-enzyme inhibitors. Enalapril maleate (MK421), ${ }^{4}$ an orally active converting-enzyme inhibitor devoid of a sulphydryl group, may permit long-term inhibition of angiotensin II formation without incurring the side effects seen with captopril. We report preliminary results of the use of longterm enalapril in five patients with hypertension and renal artery stenosis. Particular attention was paid to the magnitude and duration of the reduction in plasma angiotensin II concentrations.

\section{Patients and methods}

Five patients (two women) aged 38-56 years gave informed consent to the study, which was approved by the hospital's ethical supervisory committee. All patients had unilateral renal artery stenosis shown by intravenous pyelography, renal arteriography, isotope nephrography, ${ }^{5}$ bilateral renal vein renin measurements, and ureteric catheter studies. ${ }^{16}$ Four had radiological evidence of atheroma and one fibromuscular hyperplasia. All had normal serum electrolyte values and renal 
function (mean serum creatinine concentration $89 \pm \mathrm{SEM} 4 \mu \mathrm{mol} / \mathrm{l}$; $1.0 \pm 0.04 \mathrm{mg} / 100 \mathrm{ml})$. Four had had an unsatisfactory hypotensive response to beta-blocker plus diuretic, together with either hydralazine (two patients), prazosin (one patient), or minoxidil (one patient). One patient had received diuretic only with poor response. Mean outpatient blood pressure on previous treatment was $189 \pm 21 / 105 \pm 5$ (SEM) $\mathrm{mm} \mathrm{Hg}$.

Patients were admitted and ate a normal ward diet. All treatment was stopped at least 14 days before enalapril was started. Placebo was given as a single morning dose for five days before active drug was administered; thereafter enalapril was given also as a single morning dose. The first three patients were the subject of a dose-finding study and began with $1.25 \mathrm{mg}$ of enalapril, which was then increased to $2.5 \mathrm{mg}, 5 \mathrm{mg}, 10 \mathrm{mg}, 20 \mathrm{mg}$, and $40 \mathrm{mg}$ on successive days; these patients were then discharged taking $40 \mathrm{mg}$ daily. After analysis of blood pressure and biochemical data in these three patients the subsequent two began treatment with $10 \mathrm{mg}$ daily, which was continued for each of the six days of inpatient stay. After discharge the enalapril dose was adjusted until supine and erect blood pressures were below $140 \mathrm{~mm} \mathrm{Hg}$ systolic and $90 \mathrm{~mm} \mathrm{Hg}$ diastolic (phase V) four hours after the morning dose, or until a maximum dose of $40 \mathrm{mg}$ daily was reached. After 12 weeks two patients were receiving $40 \mathrm{mg}$, one $20 \mathrm{mg}$, and two $10 \mathrm{mg}$ daily.

Measurements of plasma active renin concentration (normal range $10-50 \mathrm{mU} / \mathrm{l}){ }^{7}$ blood angiotensin I $(2 \cdot 3-15 \cdot 5 \mathrm{pmol} / 1 ; 3-20 \mathrm{pg} / \mathrm{ml}),{ }^{8}$ plasma angiotensin II $(5-35 \mathrm{pmol} / 1 ; 5-35 \mathrm{pg} / \mathrm{ml}),{ }^{9}$ plasma aldosterone $(<500 \mathrm{pmol} / \mathrm{l} ;<180 \mathrm{pg} / \mathrm{ml}),{ }^{10}$ and plasma converting-enzyme activity $^{11}$ were made after 30 minutes' recumbency before the first dose of enalapril and two, six, and 24 hours later; supine and erect blood pressure was recorded after blood sampling using the Hawksley random-zero sphygmomanometer. These measurements were repeated after 12 weeks of treatment under identical conditions. Measurements were made of total body and exchangeable sodium and potassium before and during long-term treatment. ${ }^{12-14}$

Data were analysed using repeated measures analysis of variance, with logarithmic transformation where appropriate. Blood pressures were compared at a total of six time points: before dosing and two and six hours later, after three months of enalapril, and at corresponding times before treatment. Concentrations of renin, angiotensins I and II, and aldosterone and converting-enzyme activity were compared at three time points: before treatment and before and two hours after daily dosing at three months. Comparisons were based on Scheffé multiple comparisons at the $1 \%$ level to guarantee an overall significance level of at most $5 \%$ for the five variables jointly.

\section{Results}

Dose-finding study-Parallel falls of plasma angiotensin II concentrations and converting-enzyme activity were apparent two hours after enalapril, increasing with increasing dosage; at all doses the effects were waning 24 hours later (figure). Blood pressure did not fall significantly during dose finding from the initial $180 \pm 11 / 103 \pm 5$ $\mathrm{mm} \mathrm{Hg}$.

Long-term enalapril-During long-term treatment plasma converting-enzyme activity and angiotensin II concentrations were not

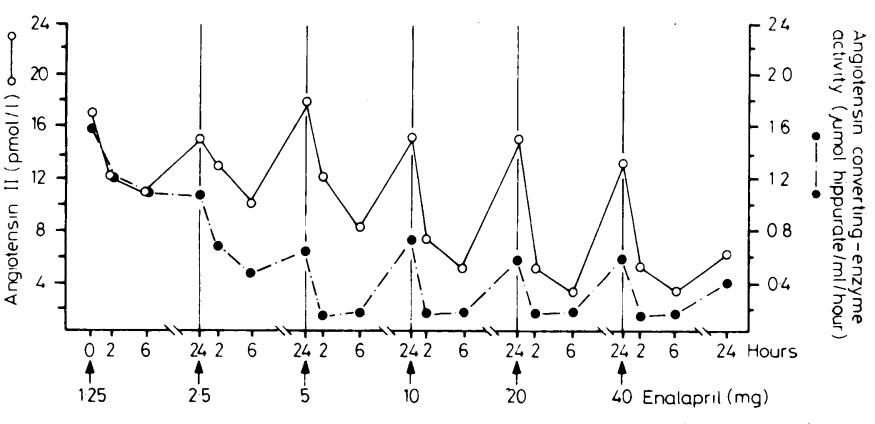

Results of dose-finding study in three patients. Changes in mean plasma angiotensin II concentrations and angiotensin converting-enzyme activity with increasing daily dosage of enalapril.

Conversion: SI to traditional units-Angiotensin II: $1 \mathrm{pmol} / \mathrm{l} \approx 1 \mathrm{pg} / \mathrm{ml}$. Angiotensin converting-enzyme activity: $1 \mu \mathrm{mol}$ hippurate $/ \mathrm{ml} / \mathrm{hour} \approx 179 \mu \mathrm{g}$ hippurate/ml/hour significantly reduced 24 hours after the last dose, though active renirm and angiotensin I concentrations were raised. Two hours after the morning dose renin and angiotensin I values had risen further, while plasma angiotensin II concentrations and converting-enzyme activity? were significantly depressed. The mean plasma aldosterone concen? tration was not significantly lowered during long-term enalapri treatment (table). Despite these biochemical variations there were

Mean ( $\perp S E M)$ changes in components of renin-angiotensin system during treatment with enalapril

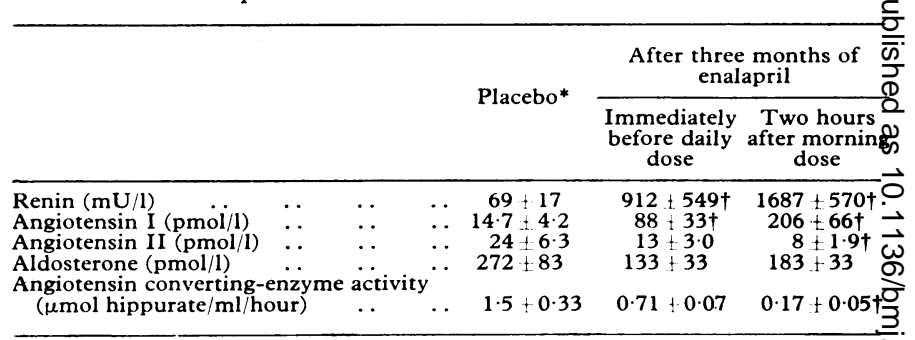

*Placebo values immediately before first dose of enalapril at start of treatment.

$t \mathrm{p}<0.05$ compared with placebo value. Conversion: SI to traditional units-Angiotensin $1: 1 \mathrm{pmol} / 1 \approx 1.3 \mathrm{pg} / \mathrm{ml}$. Angio
tensin II : $1 \mathrm{pmol} / 1 \approx 1 \mathrm{pg} / \mathrm{ml}$. Aldosterone: $1 \mathrm{pmol} / 1 \approx 0.04 \mathrm{ng} / 100 \mathrm{ml}$. Angiotension converting-enzyme activity: $1 \mathrm{\mu mol}$ hippurate $/ \mathrm{ml} / \mathrm{hour} \approx 179 \mathrm{\mu g}$ hippurate $/ \mathrm{ml} / \mathrm{hour}$

consistent falls in blood pressure, from average pretreatment inpatient values of $190 \pm 2 / 101 \pm 1 \mathrm{~mm} \mathrm{Hg}$ supine (mean $\pm S E M$ ) and $181 \pm 3 \not$ $105 \pm 1$ erect, to $144 \pm 3 / 83 \pm 1 \mathrm{~mm} \mathrm{Hg}$ supine and $127 \pm 4 / 83 \pm z_{4}$ erect $(p<0.05$ for all comparisons before treatment versus long-term treatment before and two and six hours from dosing). Neither serung sodium nor serum potassium values were significantly altered bळ long-term enalapril (respective means $\pm S E M 142 \pm 0.5$ and $3.8 \pm 0$. P $\mathrm{mmol}(\mathrm{mEq}) / \mathrm{l}$ before treatment, and $142 \pm 0.7$ and $4.1 \pm 0.2 \mathrm{mmol} / \Phi$ during treatment). Similarly exchangeable sodium $(102 \cdot 2 \pm \mathrm{SEM}$ $2.5 \%$ of predicted normal versus $97.8 \pm 2.9 \%$ ), exchangeable potassium $(99 \cdot 1 \pm 2.5 \%$ versus $100 \cdot 2 \pm 1 \cdot 6 \%)$, total body sodiunt $(103.5 \pm 4.5 \%$ versus $100 \cdot 5 \pm 4.2 \%)$, and total body potassiun $(103 \cdot 2 \pm 4.5 \%$ versus $101 \cdot 2 \pm 3 \cdot 1 \%)$ were not significantly changed There was a slight but significant $(\mathrm{p}<0.05)$ increase in serump creatinine concentration with long-term treatment (mean $89 \pm S E M$ to $115 \pm 7 \mu \mathrm{mol} / 1 ; 1.0 \pm 0.05$ to $1.3 \pm 0.08 \mathrm{mg} / 100 \mathrm{ml})$.

Side effects-No serious side effects were encountered. One patien $₫$ developed tachycardia in the standing position; supine and erect pulse rates rose from 72 and 73 during the placebo period to 82 anc 129 at one week and 79 and 107 at three months. The same patient noted worsening of pre-existing Raynaud's phenomenon. In all case enalapril was associated with an increased feeling of wellbeing, and one man recovered previously impaired sexual function. No instance of disturbance of taste, rash, leucopenia, glycosuria, or proteinuria were encountered.

\section{Discussion}

None of these patients has required an operation. Thus proof of the role of the renal artery lesion in causing hypertension is lacking, and we cannot comment on the value of long-termo enalapril as a guide to surgical outcome.

Enalapril is more powerful and sustained in its action than captopril. ${ }^{15}$ Captopril, given as $150 \mathrm{mg}$ three times daily, does suppress the plasma angiotensin II concentration over 24 hours Studies in healthy volunteers ${ }^{16}$ show that, given acutely in single daily dose of $20 \mathrm{mg}$, enalapril does not fully suppres $\$$ plasma angiotensin II over 24 hours. Our results suggest similaf ${ }^{+}$ lack of complete suppression with long-term use. Nevertheless blood pressure remained well controlled at all times studieç्户 during prolonged treatment; indeed, the lower blood pressure seen in every patient during long-term treatment than in the first week might in part result from elimination of the slow pressor action of angiotensin II. ${ }^{17}$

These preliminary findings thus provide evidence of the्巳 efficacy and tolerability of enalapril in the medical treatment of̂. hypertension with renal artery stenosis. 
We acknowledge support for this study from Dr P M Lutterbeck, Merck, Sharp and Dohme Limited.

\section{References}

' Atkinson AB, Brown JJ, Cumming AMM, et al. Captopril in renovascular hypertension: long-term use in predicting surgical outcome. $\mathrm{Br} \mathrm{Med} \mathcal{F}$ $1982 ; 284: 689-93,1557$.

- Atkinson AB, Cumming AMM, Brown JJ, et al. Captopril treatment: inter-dose variations in renin, angiotensins I and II, aldosterone and blood pressure. Br 7 Clin Pharmacol 1982;13:855-8.

"Heel RC, Brogden RN, Speight TM, Avery GS. Captopril: a preliminary review of its pharmacological properties and therapeutic efficacy. Drugs $1980 ; 20: 409-52$.

${ }^{4}$ Patchett AA, Harris E, Tristram EW, et al. A new class of angiotensinconverting enzyme inhibitors. Nature $1980 ; 288: 280-3$.

Mackay A, Eadie AS, Cumming AMM, Graham AG, Adams FG, Horton PW. Assessment of total and divided renal plasma flow by ${ }^{123}$ I-hippuran renography. Kidney Int 1981;19:49-57.

${ }^{6}$ Brown JJ, Lever AF, Robertson JIS. Renal hypertension: diagnosis and treatment. In: Black D, Jones NF, eds. Renal disease. 4th ed. Oxford: Blackwell, 1979:731-65.

' Millar JA, Leckie B, Semple PF, Morton JJ, Sonkodi S, Robertson JIS. Active and inactive renin in human plasma: renal arteriovenous differences and relationships with angiotensin and renin-substrate. Circ Res 1978;43,suppl 1:120-7.

* Waite MA. Measurement of concentrations of angiotensin I in human blood by radioimmunoassay. Clinical Science and Molecular Medicine $1973 ; 45: 51-64$.

"Atkinson AB, Morton JJ, Brown JJ, et al. Captopril in clinical hyper- tension: changes in components of the renin-angiotensin system and in body composition in relation to fall in blood pressure with a note on measurement of angiotensin II during converting enzyme inhibition. Br Heart $\mathcal{F} 1980 ; 44: 290-6$.

10 Fraser R, Guest S, Young J. Comparison of double isotope derivative and radioimmunological estimation of plasma aldosterone concentration. Clinical Science and Molecular Medicine 1973;45:411-5.

1 Cushman DW, Cheung HS. Spectrophotometric assay and properties of the angiotensin-converting enzyme of rabbit lung. Biochem Pharmacol $1971 ; 20: 1637$.

12 Davies DL, Robertson JWK. Simultaneous measurement of total exchangeable potassium and sodium using ${ }^{43} \mathrm{~K}$ and ${ }^{24} \mathrm{Na}$. Metabolism $1973 ; 22$ : 133-7.

${ }^{13}$ Boddy K, King PC, Tothill P, Strong JA. Measurement of total body potassium with a shadow shield whole-body counter: calibration and errors. Phys Med Biol 1971;16:275-82.

14 Williams ED, Boddy K, Harvey I, Haywood JK. Calibration and evaluation of a system for total body in vivo activation analysis using $14 \mathrm{MeV}$ neutrons. Phys Med Biol 1978;23:405-15.

15 Gross DM, Sweet CS, Ulm EH, et al. Effect of N- \{(S)-1-carboxy-3phenyl propyl- \} L-Ala-L-Pro and its ethyl esther (MK421) on angiotensin converting enzyme in vitro and angiotensin I pressor responses in vivo. I Pharmacol Exp Ther 1981 ;217:552-7.

${ }^{16}$ MacGregor AG, Markandu ND, Bayliss J, Roulston JE, Squires $M$, Morton JJ. Non-sulphydryl-containing angiotensin-converting enzyme inhibitor (MK421): evidence for role of renin system in normotensive subjects. $B r$ Med f $1981 ; 283: 401-3$.

17 Brown JJ, Casals-Stenzel J, Cumming AMM, et al. Angiotensin II, aldosterone and arterial pressure: a quantitative approach. Hypertension $1979 ; 1: 159-79$.

(Accepted 11 October 1982)

\title{
Early prognosis of epilepsy
}

\author{
S D SHORVON, E H REYNOLDS
}

\begin{abstract}
In 94 previously untreated new referrals to a neurological clinic with tonic-clonic or partial seizures or both the failure rate for optimum single-drug treatment with phenytoin or carbamazepine after a median of 32 months was $17 \%$. Failure of single-drug treatment was associated especially with the presence of additional neuropsychiatric handicaps but also with partial or mixed seizures, symptomatic epilepsy, and a higher number and frequency of tonic-clonic or partial seizures before treatment. Analysis of the recurrence of seizures suggested that the first year of treatment may be crucial in determining the long-term prognosis.

These findings are in keeping with the concept that seizures may predispose to further seizures, and imply that early, effective treatment may be important to prevent evolution into chronic and more intractable epilepsy.
\end{abstract}

\section{Introduction}

Epilepsy is usually a chronic disorder with a widely varying outcome.' ' There has been little prospective study, however, of

\footnotetext{
University Department of Neurology, King's College Hospital, London SE5 9RS

S D SHORVON, MB, MRCP, honorary registrar (present appointment: senior registrar, National Hospital, Queen Square, London WC1)

E H REYNOLDS, MD, FRCP, consultant neurologist
}

the factors that influence prognosis. ${ }^{3} \operatorname{Rodin}^{1}$ in his detailed review commented that most reports were retrospective surveys of selected groups of patients with chronic epilepsy who had gravitated to institutions or hospital clinics, often with inadequate documentation and follow-up.

In the past six years we have undertaken studies of single-drug treatment with either phenytoin or carbamazepine, in which we have monitored drug concentrations, in new referrals to a neurological clinic with previously untreated tonic-clonic or partial seizures, or both. In addition to the pharmacological aspects already reported ${ }^{4-7}$ this has given us the opportunity of studying for the first time, prospectively and from the onset of epilepsy, factors that influence the prognosis for control of seizures.

\section{Patients and methods}

We studied 106 consecutive referrals to a neurological clinic with tonic-clonic or partial epilepsy, or both, who had not been treated previously, had no progressive cerebral disorder, and had had two or more recent tonic-clonic seizures or sufficient partial seizures to warrant treatment. Details of the treatment regimen with either phenytoin or carbamazepine and of the blood concentration monitoring have been reported previously. ${ }^{4-6}$ Our policy was to begin with a small dose of one drug, monitor the blood concentration of the drug at each clinic visit, and increase the dose by small increments, if necessary into the optimum range of blood concentrations for that drug as dictated clinically by the recurrence of seizures, except where there was evidence that the recurrence was due to poor compliance. Two or more seizures despite blood drug concentrations in the optimum range were regarded as evidence of failure of single-drug treatment. Optimum drug concentrations were phenytoin $40-80 \mu \mathrm{mol} / 1$ and carbamazepine $16-32 \mu \mathrm{mol} / 1$. 